\title{
CONSTRAINTS FACED BY THE AONLA GROWERS IN AGRICULTURE INFORMATION MANAGEMENT BEHAVIOUR
}

\section{CHOUDHARY. $S^{1} \&$ VIKASH PAWARIYA ${ }^{2}$}

${ }^{I}$ Scientist, KVK, Bhavnagar Gujrat, India

${ }^{2}$ Research Scholar, Department of Agriculture Economics, San college of agriculture, jobner, Jaipur, Rajasthan, India

\begin{tabular}{|l|}
\hline ABSTRACT \\
India has one of the largest and most complex public systems for generation, testing and transfer of agricultural \\
information. It is the information behaviour of the farmers, which can promote and spread the results obtained in the \\
laboratories for their better utilization in farming community. Aonlagrowers information management from different \\
sources and channels of agriculture information which have brought the aonla growers and scientists close to understand \\
the suitability of the technologies. The Semi Arid Eastern Plains Zone (IIIa) of Rajasthan has highest area and \\
production under aonla cultivation. There are so many agricultural institutions, which are engaged in the research on \\
aonlagrowers problems and transfer of technology to the aonla growers. \\
KEYWORDS:Agricultureinformation,Technical, Operational, Infra-Structural, Educational and Economic Constraints
\end{tabular}

Received: Jun 20, 2017; Accepted: Jul 05, 2017; Published: Jul 10, 2017; Paper Id.: IJASRAUG201718

\section{INTRODUCTION}

An improvement and strengthening of agricultural infrastructure needed to all the levels of supply chain. Shrinking extension is another component of infrastructure that needs attention. After the green revolution in the midsixties there has been no major technological innovation, which could give a fresh impetus to agricultural productivity, insufficient extension services and poor access to information further widen the gap in the adoption of technology and lead to poor productivity levels. A push towards higher productivity will require information based, decision making agricultural system. This is often described as the next great evolutionary step in agricultural. Today's farmers desire not only the meals for their families from their hard sweat but also surplus production which can sold in the market to get sufficient money to fulfill the daily requirements. According to economic reforms in the country each and every sector has changed its strategies in view of global competition.

Among the various sources of information mass media is an important one which consists of newspapers, magazines, traditional media, radio, TV and information technology which have proven to be the most powerful opinion makers in this information technology era. They cover more people in less time with minimum cost. This strength of mass media is of great help to extension workers in providing cost effective and efficient services to the farmers. Computers are the greatest discovery in the recent times. Internet has made the world into a global village and provides the channel for exchange of information quickly. Unfortunately the usage of information technology as a powerful medium in the field of agriculture is yet to take place effectively. 


\section{RESEARCH METHODOLOGY}

To measure the intensity of the constraints as perceived by the respondents, the respondents were asked to express their perception about the different anticipated constraints. The perceived intensity of constraints was quantified by assigning the scores using the four point continuum scale viz., 'most severe', 'severe', 'least severe' and 'not severe' with a score of 3,2,1 and 0, respectively. The constraint score of a particular constraint was worked out by totaling the scores obtained by that particular constraint by allthe respondents. Then, the mean percent score of each constraint was worked out and these were arranged in rank order according to their severity.

\section{RESULTS AND DISCUSSIONS}

In this section, it was tried to find out the constraints in Agriculture Information Management Behaviour of improved aonla cultivation practices as perceived by the respondents in the study area. All the possible constraints, faced by the respondents were grouped into five major categories viz., technical constraints, operational constraints, infrastructural constraints, educational constraints and economic constraints and the data regarding the constraints faced by different categories of aonla growing farmers and farm women has been presented into following sub heads.

- Distribution of aonla growers according to their different levels of perception of constraints in agriculture information management

- Technical constraints faced by aonla growing farmers and farm women in agriculture information management

- Operational constraints faced by aonla growing farmers and farm women in agriculture information management

- Infra-structural constraints faced by aonla growing farmers and farm women in agriculture information management

- Educational constraints faced by aonla growing farmers and farm women in agriculture information management

- Economic constraints faced by aonla growing farmers and farm women in agriculture information management

Distribution of Aonla Growers According to their Different Levels of Perception of Constraints in Agriculture Information Management

The constraints faced by particular aonla growing farmers and farm women were calculated by summing the scores obtained by that particular farmer in all the five components of constraints viz. technical constraints, operational constraints, infra-structural constraints, educational constraints and economic constraints. Then the aonla growing farmers and farm women were categorized into five different levels of constraints namely, very low (0-20 per cent), low (20-40 per cent), medium (40-60 per cent), high (60-80 per cent) and very high (80-100 per cent). Further the $\mathrm{X}^{2}$ value between the frequencies of aonla growing farmers and farm women in different levels were calculated to find out the significance in agreement between the aonla growing farmers and farm women.

Table 1: Distribution of Aonla Growers According to their Different Levels of Perception of Constraints in Agriculture Information Management $\mathbf{N}=\mathbf{2 4 0}$

\begin{tabular}{|c|c|c|c|c|c|c|c|}
\hline \multirow[b]{2}{*}{ S. No. } & \multirow[b]{2}{*}{$\begin{array}{c}\text { Levels of } \\
\text { Perception of } \\
\text { Constraints }\end{array}$} & \multicolumn{2}{|c|}{ Jaipur District $(n=160)$} & \multicolumn{2}{|c|}{ Ajmer district $(n=80)$} & \multicolumn{2}{|c|}{ Total respondents ( $\mathrm{N}=\mathbf{2 4 0})$} \\
\hline & & $\begin{array}{c}\text { Farmers } \\
(n=80)\end{array}$ & $\begin{array}{l}\text { Farm } \\
\text { Women } \\
(\mathbf{n}=\mathbf{8 0}) \\
\end{array}$ & $\begin{array}{c}\text { Farmers } \\
(n=40)\end{array}$ & $\begin{array}{c}\text { Farm } \\
\text { Women } \\
(n=40)\end{array}$ & $\begin{array}{c}\text { Farmers } \\
(n=120)\end{array}$ & $\begin{array}{l}\text { Farm Women } \\
\qquad(\mathbf{n}=\mathbf{1 2 0})\end{array}$ \\
\hline
\end{tabular}




\begin{tabular}{|c|l|c|c|c|c|c|c|}
\cline { 2 - 7 } 1 & $\begin{array}{l}\text { Very Low }(0-20 \\
\text { per cent })\end{array}$ & $0(0.00)$ & $0(0.00)$ & $0(0.00)$ & $0(0.00)$ & $0(0.00)$ & $0(0.00)$ \\
\hline 2 & $\begin{array}{l}\text { Low }(20-40 \text { per } \\
\text { cent) }\end{array}$ & $6(7.50)$ & $4(5.00)$ & $1(2.50)$ & $2(5.00)$ & $7(5.83)$ & $6(5.00)$ \\
\hline 3 & $\begin{array}{l}\text { Medium (40-60 } \\
\text { per cent) }\end{array}$ & $49(61.25)$ & $45(56.25)$ & $28(70.00)$ & $22(55.00)$ & $77(64.17)$ & $67(55.83)$ \\
\hline 4 & $\begin{array}{l}\text { High (60-80 per } \\
\text { cent) }\end{array}$ & $22(27.50)$ & $25(31.25)$ & $9(22.50)$ & $12(30.00)$ & $31(25.83)$ & $37(30.83)$ \\
\hline 5 & $\begin{array}{l}\text { Very high (80- } \\
100 \text { per cent) }\end{array}$ & $3(3.75)$ & $6(7.50)$ & $2(5.00)$ & $4(10.00)$ & $5(4.17)$ & $10(8.33)$ \\
\hline & Total & $\begin{array}{c}\mathbf{8 0}(\mathbf{1 0 0 . 0 0} \\
)\end{array}$ & $\mathbf{8 0}(\mathbf{1 0 0 . 0 0})$ & $\mathbf{4 0}(\mathbf{1 0 . 0 0})$ & $\mathbf{4 0}(\mathbf{1 0 . 0 0})$ & $\mathbf{1 2 0}(\mathbf{1 0 0 . 0 0})$ & $\mathbf{1 2 0}(\mathbf{1 0 0 . 0 0})$ \\
\hline
\end{tabular}

$X^{2}=265.52$ d.f $=4$ Figures in parentheses indicate percentage

The data presented in Table 1 indicated that majority of aonla growing farmers and farm women (64.17 per cent and 55.83 per cent respectively) were having medium level of constraints, whereas 5.83 per cent, 25.83 per cent and 4.17 per cent aonla growing farmers and 5.00 per cent, 30.83 per cent, and 8.33 per cent aonla growing farm women were having low, high and very high level of constraints respectively and none of the aonla growing farmers and farm women were having very low level of constraints.

The data in Table1 further indicated that majority of aonla growing farmers and farm women in Jaipur district (61.25 per cent and 56.25 per cent respectively) and majority of aonla growing farmers and farm women in Ajmer district (70.00 per cent and 55.00 per cent respectively) were having medium level of constraints, whereas 7.50 per cent, 27.50 per cent and 3.75 per cent of aonla growing farmers and 5.00 per cent, 31.25 per cent and 7.50 per cent of farm women in Jaipur district were having low, high and very high level of constraints respectively. Only 2.50 percent, 22.50 per cent and 5.00 per cent of aonla growing farmers and 5.00 percent, 30.00 per cent, and 10.00 per cent of farm women in Ajmer district were having low, high and very high level of constraints respectively, whereas none of the aonla growing farmers and farm women in both districts were having very low levelof constraints.

The calculated value of chi-square $\left(\chi^{2}\right)$ test between the scores of aonla growing farmers and farm women was found to be 265.52, which is more than its tabulated value (9.488) at 5 per cent level of significance. Hence the null hypothesis was rejected and alternate hypothesis was accepted. This leads a highly significant agreement between the aonla growing farmers and farm women in both districts of the aonla growers with regard to constraints.

\section{Technical Constraints Faced by Aonla Growing Farmers and Farm Women in Agriculture Information Management}

The data related with technical constraints faced bythe aonla growing farmers and farm women in agriculture information management were incorporated in Table 2 shows that calculated Wilcoxen ' $Z$ ' value for the technical constraints viz. 'lack of farm magazines / news papers, 'lack of agriculture information leaflets', 'difficulty in accessing right programmes in various television channels', 'less time allocation by radio/TV for agricultural programme', 'less space covered in news paper for agricultural news', 'unsuitability of the time to radio listen/ view TV for agricultural programmes', 'highly technical farm magazines/ agricultural leaflets', 'highly advanced demonstrations', 'less suitability of improved aonla cultivation practices with farmers economic condition', 'lack of articles relating to agriculture in local language' and 'lack of knowledge of available information sources'were more than the tabulated value at 5 per cent level of significance. Hence, the null hypothesis was rejected and alternate hypothesis was accepted, which leads to the 
conclusion that there is a significant difference between aonla growing farmers and farm women with respect to these technical constraints. Whereas the calculated Wilcoxen ' $Z$ ' value for the technical constraints viz. 'highly technical advises of research extension officers' and 'lack of awareness and information about latest technology' were less than the tabulated value at 5 per cent level of significance. Hence, the null hypothesis was accepted and alternate hypothesis was rejected, which leads to the conclusion that there is no significant difference between aonla growing farmers and farm women with respect to these technical constraints.

The data presented in Table 2 indicates that for aonla growing farmers and farm women "Lack of farm magazines news papers" (MPS 86.79 and 83.34 respectively) were perceived as the most severe constraints with top priority and accorded the first rank. The constraints for aonla growing farmers "Unsuitability of the time to radio listen/ view TV for agricultural programmes" (MPS 81.05) and for farm women "Difficulty in accessing right programmes in various TV channels" (MPS 77.50) were perceived as the most severe constraints with top priority and accorded the second rank respectively. Whereas, for the problem for anola growing farmers "Lack of awareness and information about latest

Table 2: Technical Constraints in Agriculture Information Management as Perceived by the Aonla Growers N=240

\begin{tabular}{|c|c|c|c|c|c|c|c|c|c|c|c|c|c|c|}
\hline \multirow{3}{*}{ S. No. } & \multirow{3}{*}{ Technical Constraints } & \multicolumn{4}{|c|}{ Jaipur District $(\mathrm{n}=160)$} & \multicolumn{4}{|c|}{ Ajmer District $(\mathrm{n}=80)$} & \multicolumn{4}{|c|}{ Total Respondents $(\mathrm{N}=\mathbf{2 4 0})$} & \multirow{3}{*}{$\begin{array}{l}\text { Wilcoxon } \\
\text { ( } \mathrm{Z} \text { value })\end{array}$} \\
\hline & & \multicolumn{2}{|c|}{$\begin{array}{c}\text { Farmers } \\
(\mathrm{n}=80)\end{array}$} & \multicolumn{2}{|c|}{$\begin{array}{l}\text { Farm Women } \\
(\mathrm{n}=80)\end{array}$} & \multicolumn{2}{|c|}{ Farmers $(\mathrm{n}=40)$} & \multicolumn{2}{|c|}{$\begin{array}{c}\text { Farm women } \\
(\mathrm{n}=40)\end{array}$} & \multicolumn{2}{|c|}{ Farmers $n=120$ ) } & \multicolumn{2}{|c|}{$\begin{array}{c}\text { Farm Women } \\
(\mathrm{n}=120)\end{array}$} & \\
\hline & & MPS & Rank & MPS & Rank & IIPS & Rank & MPS & Rank & IIPS & Rank & MPS & Rank & \\
\hline 1. & $\begin{array}{l}\text { Lack of farm magazines / } \\
\text { news papers }\end{array}$ & 91.08 & I & 87.50 & I & 82.50 & II & 79.17 & II & 86.79 & I & 83.34 & I & $2.38^{*}$ \\
\hline 2. & $\begin{array}{l}\text { Lack of agriculture } \\
\text { information leaflets. }\end{array}$ & 64.58 & XI & 69.17 & $\mathrm{XI}$ & 83.33 & I & 81.67 & I & 73.96 & VII & 75.42 & III & $2.16^{*}$ \\
\hline 3. & $\begin{array}{l}\text { Difficulty in accessing } \\
\text { right programmes in } \\
\text { various TV channels. }\end{array}$ & 81.25 & $\mathrm{v}$ & 80.00 & VI & 80.83 & IV & 75.00 & IV & 81.04 & III & 77.50 & II & $2.45^{*}$ \\
\hline 4. & $\begin{array}{l}\text { Less time allocation by } \\
\text { radio/TV for agricultural } \\
\text { programme. }\end{array}$ & 84.02 & II & 82.92 & III & 61.67 & $\mathrm{XI}$ & 67.50 & VII & 72.85 & $\mathrm{IX}$ & 75.21 & VI & $2.75^{*}$ \\
\hline 5. & $\begin{array}{l}\text { Less space covered in } \\
\text { news paper for agricultural } \\
\text { news }\end{array}$ & 80.00 & VII & 80.83 & $\mathrm{~V}$ & 81.67 & III & 64.17 & VIII & 80.84 & IV & 72.50 & VIII & $2.45^{*}$ \\
\hline 6. & $\begin{array}{l}\text { Unsuitability of the time to } \\
\text { radio listen/ view TV for } \\
\text { agricultural programmes. }\end{array}$ & 82.92 & IV & 84.17 & II & 79.17 & $\mathrm{~V}$ & 69.17 & VI & 81.05 & II & 76.67 & $\mathrm{v}$ & $3.11^{*}$ \\
\hline 7. & $\begin{array}{l}\text { Highly technical farm } \\
\text { magazines/ agricultural } \\
\text { leaflets. }\end{array}$ & 84.17 & III & 74.17 & IX & 74.17 & VII & 72.50 & $\mathrm{v}$ & 79.17 & $\mathrm{v}$ & 73.34 & VII & $2.53^{*}$ \\
\hline 8. & $\begin{array}{l}\text { Highly advanced } \\
\text { demonstrations }\end{array}$ & 80.83 & VI & 78.33 & VII & 76.67 & VI & 76.17 & III & 78.75 & VI & 77.25 & IV & $3.07^{*}$ \\
\hline 10. & $\begin{array}{l}\text { Highly technical advises of } \\
\text { research extension } \\
\text { officers. } \\
\text { Less suitability of } \\
\text { improved aonla cultivation } \\
\text { practices with farmers } \\
\text { economic condition }\end{array}$ & 69.58 & IX & 70.83 & IV & 71.67 & VIII & 58.33 & XI & 67.71 & $\mathrm{XI}$ & 66.67 & $\mathrm{XI}$ & $1.33 \mathrm{NS}$ \\
\hline 11. & $\begin{array}{l}\text { Lack of articles relating to } \\
\text { agiculture in local } \\
\text { language. }\end{array}$ & 79.17 & VIII & 75.42 & VIII & 68.33 & IX & 59.17 & $X$ & 73.75 & VIII & 67.30 & X & $2.15^{*}$ \\
\hline 12. & $\begin{array}{l}\text { Lack of knowledge of } \\
\text { available information } \\
\text { sources }\end{array}$ & 62.92 & XII & 66.25 & XII & 59.17 & XII & 54.17 & XIII & 61.05 & XII & 60.21 & XIII & $3.21^{*}$ \\
\hline 13. & $\begin{array}{l}\text { Lack of awareness and } \\
\text { information about latest } \\
\text { technology }\end{array}$ & 60.00 & XIII & 64.58 & XIII & 55.53 & XIII & 57.50 & XII & 57.77 & XIII & 61.04 & XII & $1.23 \mathrm{NS}$ \\
\hline
\end{tabular}

* = significant at 5 per cent level of significancetechnology" (MPS 57.77) and for farm women "Lack of 
knowledge of available information sources" (MPS 60.21) were perceived as the least severe constraints of the respondents.

In case of aonla growing farmers and farm women in Jaipur district "Lack of farm magazines / news papers" (MPS 91.08 and 87.50 respectively) was perceived as the most severe constraints with top priority and accorded the first rank. The constraints for aonla growing farmers "Less time allocation by radio/TV for agricultural programme" (MPS 84.02) and for farm women "Unsuitability of the time to radio listen/ view TV for agricultural programmes" (MPS 84.17) were perceived as the most severe constraints with top priority and accorded the second rank, whereas, the problem for anola growing farmers and farm women "Lack of awareness and information about latest technology" (MPS 60.00 and 64.58) was perceived as the least severe constraints of the respondents. Whereas, for aonla growing farmers and farm women in Ajmer district "Lack of agriculture information leaflets" (MPS 83.33 and 81.67 respectively) and "Lack of farm magazines / news papers" (MPS 82.50 and 79.17 respectively) were perceived as the most severe constraints with top priority and accorded the first and second ranks respectively, whereas, the problem for anola growing farmers "Lack of awareness and information about latest technology" (MPS 55.53) and for farm women "Lack of knowledge of available information sources" (MPS 57.50) were perceived as the least severe constraints of the respondents .

From the above findings it can be concluded that the problem of 'Lack of farm magazines/ journals', 'Unsuitable time to listen radio and view television for agriculture programme' and 'Difficulty in accessing right programmes in various TV channels' for agriculture news were the most severe constraints faced by the aonla growers. It was also observed that the obstacles 'Lack of knowledge of available information sources' and 'Lack of awareness and information about latest technology' were perceived least severe constraint by the aonla growers.

Among the different technical constraint the 'lack of farm magazines/ journals, perceived as the most severe constraint by all the categories of aonla growers. This might be due to the reason that most of the aonla growers lived in remote area so there was less availability of journals and magazines.

\section{Operational Constraints Faced by Aonla Growing Farmers and Farm Women in Agriculture Information Management}

The data related with operational constraints faced bythe aonla growing farmers and farm women in agriculture information management were incorporated in Table 3 shows that calculated Wilcoxen ' $Z$ ' value for the operational constraints viz. 'less uses of local language in TV/Radio/Newspaper', 'poor communication ability of extension workers', 'poor cosmopoliteness of extension workers', 'low accessibility of agriculture supervisor/V.E.W. when required', 'more distance of demonstration plots', 'less use of teaching aids by extension workers', 'lack of teaching aids with mobile agriculture extension unit', 'agents of private agencies do not have through knowledge and they provide misleading information', 'Agriculture supervisor pay very less number of visits to the farmer's field', 'only the farmers having contact with agriculture supervisor are selected for training', 'lack of co-ordination and cooperation among contact farmer's and extension personnel' and 'progressive farmers hijack the agricultural information to be provided by extension agencies'were more than the tabulated value at 5 per cent level of significance. Hence, the null hypothesis was rejected and alternate hypothesis was accepted, which leads to the conclusion that there is a significant difference between aonla growing farmers and farm women with respect to these operational constraints. Whereas the calculated Wilcoxen ' $Z$ ' value for the operational constraints viz. 'low persuasiveness of agriculture programmes in TV/ Radio' was less than the tabulated value at 5 per cent level of significance. Hence, the null hypothesis was accepted and alternate hypothesis was 
rejected, which leads to the conclusion that there is no significant difference between aonla growing farmers and farm women with respect to these operational constraints.

The data presented in Table 3 indicates that for aonla growing farmers and farm women "Less uses of local language in TV/Radio/Newspaper" (MPS 87.05 and 84.46 respectively) and "More distance of demonstration plots" (MPS 82.09 and 83.42 respectively) were perceived as the most severe constraints with top priority and accorded the first and second ranks respectively. Whereas, the problem for anola growing farmers and farm women "Progressive farmers hijack the agricultural

Table 3: Operational Constraints in Agriculture Information Management as Perceived by the Aonla Growers N=240

\begin{tabular}{|c|c|c|c|c|c|c|c|c|c|c|c|c|c|c|}
\hline \multirow{3}{*}{ S. No. } & \multirow{3}{*}{ Operational constraints } & \multicolumn{4}{|c|}{ Jaipur District (n=160) } & \multicolumn{4}{|c|}{ Ajmer District $(\mathrm{n}=80)$} & \multicolumn{4}{|c|}{ Total Respondents $(\mathrm{N}=240)$} & \multirow{3}{*}{$\begin{array}{l}\text { Wilcoson } \\
\text { (Z value) }\end{array}$} \\
\hline & & \multicolumn{2}{|c|}{ Farmers $(n=80)$} & \multicolumn{2}{|c|}{$\begin{array}{l}\text { Farm Women } \\
\quad(\mathrm{n}=80)\end{array}$} & \multicolumn{2}{|c|}{ Farmers $(n=40)$} & \multicolumn{2}{|c|}{$\begin{array}{c}\text { Farm women } \\
(\mathrm{n}=40)\end{array}$} & \multicolumn{2}{|c|}{ Farmers $(n=120)$} & \multicolumn{2}{|c|}{$\begin{array}{c}\text { Farm women } \\
(\mathrm{n}=120)\end{array}$} & \\
\hline & & IPS & Rank & IPS & Rank & IPS & Rank & IIPS & Rank & IPS & Rank & IVS & Rank & \\
\hline 1. & Less uses of local language in TVRadioN Newspaper. & 91.92 & I & 84.75 & I & 82.17 & $\mathrm{I}$ & 84.17 & I & 87.05 & I & 84.46 & I & $2.13^{*}$ \\
\hline 2. & Poor communication ability of extension workers. & 70.42 & X & 66.65 & $X$ & 76.67 & III & 63.33 & IX & 73.55 & $\mathrm{VI}$ & 64.99 & $\mathrm{IX}$ & $2.75^{*}$ \\
\hline 3. & Poor cosmopoliteness of extension workers. & 74.17 & VIII & 72.92 & VII & 75.00 & IV & 78.33 & III & 74.59 & V & 75.63 & IV & $3.81^{*}$ \\
\hline 4. & $\begin{array}{l}\text { Low accessibility of aggiculture supervisor V.E.W. when } \\
\text { required }\end{array}$ & 76.67 & VII & 71.25 & VIII & 67.50 & VII & 68.33 & VII & 72.09 & VII & 69.79 & VIII & $3.22^{*}$ \\
\hline 5. & Low persuasiveness of agiculture programmes in TV/ Radilo. & 68.75 & $\mathrm{XI}$ & 65.83 & $\mathrm{XI}$ & 64.17 & VIII & 59.17 & $\mathrm{XI}$ & 66.46 & IX & 62.50 & XII & 1.75 \\
\hline 6. & More distance of demonstation plots. & 82.5 & II & 83.50 & II & 81.67 & II & 83.33 & II & 82.09 & II & 83.42 & II & $2.67^{*}$ \\
\hline 7. & Less use of teaching aids by extension workers. & 77.08 & $\mathrm{VI}$ & 74.51 & $\mathrm{VI}$ & 72.50 & $\mathrm{~V}$ & 72.50 & $\mathrm{~V}$ & 74.79 & IV & 73.51 & $\mathrm{VI}$ & $3.49^{*}$ \\
\hline 8. & Lack of teaching aids with mobile agriculture extension unit. & 80.83 & IV & 76.67 & V & 69.17 & $\mathrm{VI}$ & 71.67 & VI & 75.00 & III & 74.17 & V & $2.12^{*}$ \\
\hline 9. & $\begin{array}{l}\text { Agents of private agencies do not have through hnowledge and } \\
\text { they provide misleading information. }\end{array}$ & 81.67 & III & 78.75 & IN & 62.50 & $\mathbb{X}$ & 66.67 & VIII & 72.09 & VII & 72.71 & VII & $3.47^{*}$ \\
\hline 10. & $\begin{array}{l}\text { Agiculture supervisor pay very less number of visits to the } \\
\text { fammer's field. }\end{array}$ & 78.75 & V & 80.00 & III & 58.33 & $\mathrm{XI}$ & 75.00 & IV & 68.54 & VIII & 77.50 & III & $2.62^{*}$ \\
\hline 11. & $\begin{array}{l}\text { Only the famers having contact with agiculture supervisor } \\
\text { are selected for training. }\end{array}$ & 65.42 & XII & 69.58 & $\mathbb{X}$ & 59.17 & $\mathrm{X}$ & 58.33 & XII & 62.30 & XI & 63.96 & $x$ & $3.31^{*}$ \\
\hline 12. & $\begin{array}{l}\text { Lack of co-ordination and cooperation among contact fammer's } \\
\text { and extension personnel. }\end{array}$ & 72.5 & IX & 64.58 & XII & 54.17 & XIII & 61.67 & $X$ & 63.34 & $X$ & 63.13 & $\mathrm{XI}$ & $2.68^{*}$ \\
\hline 13. & $\begin{array}{l}\text { Progressive famers hijack the agicultural information to be } \\
\text { provided by extension agencies. }\end{array}$ & 62.92 & XIII & 63.75 & XIII & 57.50 & XII & 54.17 & XIII & 60.21 & XII & 58.96 & XIII & $3.27^{*}$ \\
\hline
\end{tabular}

$*$ = significant at 5 per cent level of significance information to be provided by extension agencies." (MPS 60.21 and 58.96 respectively) was perceived as the least severe constraints of the respondents.

In case of aonla growing farmers and farm women in Jaipur district "Less uses of local language in TV/Radio/Newspaper" (MPS 91.92 and 84.75 respectively) and "More distance of demonstration plots" (MPS 82.50 and 83.50 respectively) were perceived as the most severe constraints with top priority and accorded the first and second ranks respectively, whereas, the problem for anola growing farmers and farm women "Progressive farmers hijack the agricultural information to be provided by extension agencies" (MPS 62.92 and 63.75 respectively) was perceived as the least severe constraints of the respondents. Whereas, for aonla growing farmers and farm women in Ajmer district "Less uses of local language in TV/Radio/Newspaper" (MPS 82.17 and 84.17 respectively) and "More distance of demonstration plots" (MPS 81.67 and 83.33 respectively) were perceived as the most severe constraints with top priority and accorded the first and second ranks respectively, whereas, the problem for anola growing farmers "Lack of co-ordination and cooperation among contact farmer's and extension personnel." (MPS 54.17) and for farm women "Progressive farmers hijack the agricultural information to be provided by extension agencies" (MPS 54.17) were perceived as the least severe constraints of the respondents. 
Hence, it can be concluded that 'less uses of local language in television/ radio/ newspaper was most severe problem of aonla growers. The reason behind this might be that majority of aonla growers have less education and they less understand any scientific theme broadcasted in radio, telecasted in television and published in newspaper.

Infra-Structural Constraints Faced by Aonla Growing Farmers and Farm Women in Agriculture Information Management

The data related with infra-structural constraints of agriculture information of the aonla growing farmers and farm women in agriculture information management were incorporated in Table 4 shows that calculated Wilcoxen ' $Z$ ' value for the infra-structural constraints viz. 'lack of telephone facilities', 'difficulty of access to agriculture programmes through radio /TV due to irregular electricity supply', 'poor communication facilities', 'lack of availability of newspaper in remote areas' and 'lack of transportation facilities'were more than the tabulated value at 5 per cent level of significance. Hence, the null hypothesis was rejected and alternate hypothesis was accepted, which leads to the conclusion that there is a significant difference between aonla growing farmers and farm women with respect to these infra-structural constraints. Whereas the calculated Wilcoxen ' $Z$ ' value for the 'lack of E-mail/internet facilities' was less than the tabulated value at 5 per cent level of significance. Hence, the null hypothesis was accepted and alternate hypothesis was rejected, which leads to the conclusion that there is no significant difference between aonla growing farmers and farm women with respect to these infra-structural constraints.

The data presented in Table 4 indicates that for aonla growing farmers and farm women "Lack of E-mail/internet facilities" (MPS 84.29 and 84.42 respectively) and "Difficulty of access to agriculture programmes through radio/TV due to irregular electricity supply" (MPS 81.71 and 80.63 respectively) were perceived as the most severe constraints with top priority and was accorded the first and second ranks respectively. Whereas, the problem for anola growing farmers "Lack of telephone facilities" (MPS 67.71) and for farm women "Poor communication facilities" (MPS 63.96) were perceived as the least severe constraints of the respondents.

In case of aonla growing farmers and farm women in Jaipur district "Lack of E-mail/internet facilities" (MPS 84.58 and 83.33 respectively) and "Difficulty of access to agriculture programmes through radio/TV due to irregular electricity supply" (MPS 81.25 and 79.58 respectively) were perceived as the most severe constraints with top priority and accorded the first and second ranks respectively, whereas, the problem for anola growingfarmers"Lack of telephone facilities" (MPS 56.25) and for farm women "Poor communication facilities" (MPS 62.08) were perceived as the least severe constraints of the respondents. 
Table 4: Infra-Structural Constraints in Agriculture Information Management as Perceived by the Aonla Growers N=240

\begin{tabular}{|c|c|c|c|c|c|c|c|c|c|c|c|c|c|c|}
\hline \multirow{3}{*}{ S.1.10. } & \multirow{3}{*}{ Infra-Structural Constraimts } & \multicolumn{4}{|c|}{ Jaipur District (11=160) } & \multicolumn{4}{|c|}{ djmer District ( $(\mathrm{n}=80)$} & \multicolumn{4}{|c|}{ Total Respondents (. $=2.40)$} & \multirow{3}{*}{$\begin{array}{l}\text { Tilcoson } \\
\text { (Zralue })\end{array}$} \\
\hline & & \multicolumn{2}{|c|}{ Farmers $n=80)$} & \multicolumn{2}{|c|}{$\begin{array}{c}\text { Farm Women } \\
(\mathrm{n}=80)\end{array}$} & \multicolumn{2}{|c|}{ Farmers $(\mathbb{1}=40)$} & \multicolumn{2}{|c|}{$\begin{array}{c}\text { Farm Women } \\
(\mathrm{n}=40)\end{array}$} & \multicolumn{2}{|c|}{ Farmers $(\mathbb{1}=120)$} & \multicolumn{2}{|c|}{$\begin{array}{l}\text { Farm Women } \\
(\mathrm{n}=120)\end{array}$} & \\
\hline & & IIPS & Rank & IIPS & Rank & IIPS & Rank & IIPS & Rank & IIPS & Rank & $\mathbb{I P S}$ & Rank & \\
\hline 1. & Ladk of E-mall intemet facillites & 84.58 & I & 83.33 & 1 & 84.00 & I & 85.50 & I & 84.29 & I & 84.42 & I & $2.62^{*}$ \\
\hline 2. & Lack of telephlone facilities & 56.25 & VI & 77.92 & III & 79.17 & III & 77.50 & III & 67.71 & VI & 77.71 & III & 1.71 \\
\hline 3. & $\begin{array}{l}\text { Difficulty of access to agriculture progogammes through adio IV } \\
\text { due to imegular electricty supply. }\end{array}$ & 81.25 & $\mathbb{I}$ & 79.58 & $\mathbb{I}$ & 82.17 & $\mathbb{I}$ & 81.67 & II & 81.71 & II & 80.63 & II & $2.64^{*}$ \\
\hline 4. & Poor communication facilities. & 70.42 & V & 62.08 & VI & 67.50 & VI & 65.83 & VI & 68.96 & V & 63.96 & VI & $2.98^{*}$ \\
\hline 5. & Lack of aralalability of nersspaper in remote areas. & 76.25 & III & 65.00 & V & 72.50 & V & 72.50 & $V$ & 74.38 & IN & 68.75 & $V$ & $2.37^{*}$ \\
\hline 6. & Lack of tannspotration facilites. & 73.67 & IN & 73.75 & IV & 76.67 & IV & 75.83 & IV & 75.17 & III & 74.79 & IN & $236^{*}$ \\
\hline
\end{tabular}

$*$ = significant at 5 per cent level of significance

Whereas, for aonla growing farmers and farm women in Ajmer district "Lack of E-mail/internet facilities" (MPS 84.00 and 85.50 respectively) and "Difficulty of access to agriculture programmes through radio/TV due to irregular electricity supply" (MPS 82.17 and 81.67 respectively) were perceived as the most severe constraints with top priority and accorded the first and second ranks respectively, whereas, the problem for anola growing farmers and farm women "Poor communication facilities" (MPS 67.50 and 65.83) was perceived as the least severe constraints of the respondents.

The findings revealed that the lack of internet/ e-mail facilities was perceived as the most severe constraints by all the categories of aonla growers. The reason behind this might be due to that the cost of computer was high and less technical knowledge about internet/ e-mail to aonla growers so, these was most difficult constraints.

Educational Constraints Faced by Aonla Growing Farmers and Farm Women in Agriculture Information Management

The data related with educational constraints of agriculture information of the aonla growing farmers and farm women in agriculture information management were incorporated in Table 5 shows that calculated Wilcoxen ' $Z$ ' value for the group contact sources viz. 'poor education/literacy of respondents', 'lack of knowledge about progressive farmers', 'lack of time for accessing the information', 'lack of knowledge of contact farmers' and 'lack of success stories about progressive farmers in the area' were more than the tabulated value at 5 per cent level of significance. Hence, the null hypothesis was rejected and alternate hypothesis was accepted, which leads to the conclusion that there is a significant difference between aonla growing farmers and farm women with respect to these educational constraints. Whereas the calculated Wilcoxen 'Z' value for the 'lack of knowledge about agriculture information providers' was less than the tabulated value at 5 per cent level of significance. Hence, the null hypothesis was accepted and alternate hypothesis was rejected, which leads to the conclusion that there is no significant difference between aonla growing farmers and farm women with respect to these educational constraints.

The data presented in Table 5 indicates that for aonla growing farmers "Lack of time for accessing the information" (MPS 81.05) and for farm women "Poor education/literacy of respondents" (MPS 82.09) were perceived as 
the most severe constraints with top priority and was accorded the first rank, however, for aonla growing farmers and farm women "Lack of knowledge about progressive farmers" (MPS 78.96 and 77.50) was perceived as the most severe constraints with top priority and accorded the second rank. Whereas, the problem for anola growing farmers "Lack of knowledge about progressive farmers" (MPS 61.67) and farm women "Lack of success stories about progressive farmers in the area" (MPS 65.00) were perceived as the least severe constraints of the respondents.

In case of aonla growing farmers "Lack of time for accessing the information" (MPS 80.42) and farm women "Poor education/literacy of respondents" (MPS 83.33) in Jaipur district were perceived as the most severe constraints with top priority and accorded the first rank, however, for aonla growing farmers "Lack of knowledge of contact farmers" (MPS 78.75) and for farm women "Lack of knowledge about agriculture information providers" (MPS 79.17) were perceived as the most severe constraints with top priority and accorded the second rank. whereas, the problem for anola growing farmers and farm women "Lack of knowledge about progressive farmers" (MPS 59.17 and 58.75) was perceived as the least severe constraints of the respondents. Whereas, for the aonla growing farmers "Lack of knowledge about agriculture information providers" (MPS 85.00) and for farm women "Poor education/literacy of respondents" (MPS 81.67) in Ajmer district were perceived as the most severe constraints with top priority and accorded the first rank, however, for aonla growing farmers "Lack of time for accessing the information" (MPS 81.67) and for farm women "Lack of knowledge about agriculture information providers" (MPS 75.83) were perceived as the most severe constraints with top priority and accorded the second rank. whereas, the problem for anola growing farmers "Lack of knowledge of contact farmers" (MPS 60.83) and for farm women "Lack of time for accessing the information" (MPS 63.33) were perceived as the least severe constraints of the respondents.

\section{Table 5: Educational Constraints in Agriculture Information Management as Perceived by the Aonla Growers N=240}

\begin{tabular}{|c|c|c|c|c|c|c|c|c|c|c|c|c|c|c|}
\hline \multirow{3}{*}{ S. $\mathrm{NO}_{0 .}$} & \multirow{3}{*}{ Infra-Structural Constraints } & \multicolumn{4}{|c|}{ Jaipur District (n=160) } & \multicolumn{4}{|c|}{ Ajmer District ( $\mathrm{n}=80)$} & \multicolumn{4}{|c|}{ Total Respondents $(\mathrm{N}=240)$} & \multirow{3}{*}{ (Z villue $)$} \\
\hline & & \multicolumn{2}{|c|}{ Farmers $n=80$ ) } & \multicolumn{2}{|c|}{$\begin{array}{c}\text { Farm Women } \\
(\mathrm{n}=80)\end{array}$} & \multicolumn{2}{|c|}{ Farmers $(n=40)$} & \multicolumn{2}{|c|}{$\begin{array}{c}\text { Farm Women } \\
(\mathrm{n}=40)\end{array}$} & \multicolumn{2}{|c|}{ Farmers $(\mathrm{n}=120)$} & \multicolumn{2}{|c|}{$\begin{array}{c}\text { Farm Women } \\
(\mathrm{n}=120)\end{array}$} & \\
\hline & & IIPS & Rank & IPS & Rank & IPS & Rank & IPS & Rank & IIPS & Rank & IPS & Rank & \\
\hline 1. & Lack of E-mall intemet facilities & 84.58 & I & 83.33 & I & 84.00 & I & 85.50 & I & 84.29 & I & 84.42 & I & $2.62^{*}$ \\
\hline 2. & Lack of telephone facilities & 56.25 & VI & 77.92 & III & 79.17 & III & 77.50 & III & 67.71 & VI & 77.71 & III & 1.71 \\
\hline 3. & $\begin{array}{l}\text { Difficulty of access to agiculture programmes through radio TV } \\
\text { due to iregular electricity supply. }\end{array}$ & 81.25 & II & 79.58 & II & 82.17 & II & 81.67 & II & 81.71 & II & 80.63 & II & $2.64^{*}$ \\
\hline 4. & Poor communication facilities. & 70.42 & V & 62.08 & VI & 67.50 & VI & 65.83 & VI & 68.96 & V & 63.96 & VI & $2.98^{*}$ \\
\hline 5. & Lack of arailability of newsppaper in remote areas. & 76.25 & III & 65.00 & V & 72.50 & V & 72.50 & V & 74.38 & IV & 68.75 & V & $2.37^{*}$ \\
\hline 6. & Lack of tanspoortation facilities. & 73.67 & IV & 73.75 & IV & 76.67 & IV & 75.83 & IV & 75.17 & III & 74.79 & IV & $2.36^{*}$ \\
\hline
\end{tabular}

$*$ = significant at 5 per cent level of significanceThe findings revealed that the lack of time for accessing the information' was perceived most severe constraints with top priority. This might be due to the reason that many activities i.e. demonstration, meetings and training conducted by agriculture supervisor, AAOs, AOs and subject matter specialists. These activities organized mostly at 'day time' in crop season therefore, farmers are not access these information due to lack of time. 


\section{Economic Constraints Faced by Aonla Growing Farmers and Farm Women in Agriculture Information Management}

The data related with economic constraints of agriculture information of the aonla growing farmers and farm women in agriculture information management were incorporated in Table 6 shows that calculated Wilcoxen ' $Z$ ' value for the group contact sources viz. 'high charges of internet access in market', 'high cost of magazines/news papers etc.', 'high charge of traveling ticket', 'high charges of cable TV', 'high cost of DTH service', 'high cost of HYV seeds' and 'high cost of equipments (sprays and dusters)'were more than the tabulated value at 5 per cent level of significance. Hence, the null hypothesis was rejected and alternate hypothesis was accepted, which leads to the conclusion that there is a significant difference between aonla growing farmers and farm women with respect to these economic constraints. Whereas the calculated Wilcoxen ' $Z$ ' value for the 'high cost of telephone calls' was less than the tabulated value at 5 per cent level of significance. Hence, the null hypothesis was accepted and alternate hypothesis was rejected, which leads to the conclusion that there is no significant difference between aonla growing farmers and farm women with respect to these economic constraints.

The data presented in Table 6 indicates that for aonla growing farmers and farm women "High charge of traveling ticket" (MPS 79.79 and 81.46 respectively) and "High charges of internet access in market" (MPS 77.50 and 80.04 respectively) were perceived as the most severe constraints with top priority and accorded the first and second ranks respectively. Whereas, the problem for anola growing farmers and farm women "High cost of equipments (sprays and dusters)" (MPS 58.75 and 59.17) was perceived as the least severe constraints of the respondents.

In case of aonla growing farmers and farm women in Jaipur district "High charge of traveling ticket" (MPS 78.75 and 80.42 respectively) and "High charges of internet access in market" (MPS 77.50 and 79.58 respectively) were perceived as the most severe constraints with top priority and accorded the first and second ranks respectively. Whereas, the problem for anola growing farmers and farm women "High cost of equipments (sprays and dusters)" (MPS 55.83 and 61.67) was perceived as the least severe constraints of the respondents. Whereas, for aonla growing farmers "High charge of traveling ticket" (MPS 80.83 and 82.50 respectively) and "High charges of internet access in market" (MPS 77.50 and 80.50 respectively) in Ajmer district were perceived as the most severe constraints with top priority and accorded the first and second ranks respectively. Whereas, the problem for anola growing farmers "High cost of HYV seeds" (MPS 58.33) and for farm women "High cost of equipments (sprays and dusters)" (MPS 56.67) were perceived as the least severe constraints of the respondents.

The findings revealed that the 'high charge of traveling ticket' was perceived as the most severe constraint by all the categories of aonla growers. This might be due to the fact that agriculture research station, KrishiVigyan Kendra, NGOs, agriculture colleges and other related agriculture institutions are away from the majority of farmers therefore, the traveling charges were high. 
Table: 6 Economic Constraints in Agriculture Information Management as Perceived by the Aonla Growers N=240

\begin{tabular}{|c|c|c|c|c|c|c|c|c|c|c|c|c|c|c|}
\hline \multirow{3}{*}{ S. No. } & \multirow{3}{*}{ Economic Constraints } & \multicolumn{4}{|c|}{ Jaipur District (n=l60) } & \multicolumn{4}{|c|}{ Ajmer District $(\mathrm{n}=80)$} & \multicolumn{4}{|c|}{ Total Respondents $(\mathrm{N}=240)$} & \multirow{3}{*}{$\begin{array}{l}\text { Wilcoxon } \\
\text { (Z Value) }\end{array}$} \\
\hline & & \multicolumn{2}{|c|}{ Farmers $(\mathrm{n}=80)$} & \multicolumn{2}{|c|}{$\begin{array}{c}\text { Farm Women } \\
(\mathrm{n}=80)\end{array}$} & \multicolumn{2}{|c|}{ Farmers $(\mathrm{n}=40)$} & \multicolumn{2}{|c|}{$\begin{array}{l}\text { Farm Women } \\
(\mathrm{n}=40)\end{array}$} & \multicolumn{2}{|c|}{ Farmers $(n=120)$} & \multicolumn{2}{|c|}{$\begin{array}{c}\text { Farm Women } \\
(\mathrm{n}=120)\end{array}$} & \\
\hline & & VPS & Rank & IIPS & Rank & IIPS & Rank & IIPS & Rank & IPS & Rank & IIPS & Rank & \\
\hline 1. & High charges of intemet access in market. & 77.5 & II & 79.58 & II & 77.5 & II & 80.5 & II & 77.50 & II & 80.04 & II & $3.04^{*}$ \\
\hline 2. & High cost of magazines /news papers etc. & 71.67 & III & 78.33 & III & 70.17 & III & 75.83 & IV & 70.92 & III & 77.08 & III & $2.40^{*}$ \\
\hline 3. & High cost of telephone calls. & 66.67 & VI & 68.33 & VI & 64.17 & VI & 76.67 & III & 65.42 & VI & 72.50 & IV & 1.83 \\
\hline 4. & High charge of traveling ticket. & 78.75 & I & 80.42 & I & 80.83 & I & 82.5 & I & 79.79 & I & 81.46 & I & $2.50^{*}$ \\
\hline 5. & High charges of cable TV. & 69.58 & IV & 69.17 & $\mathrm{~V}$ & 67.5 & V & 73.33 & $\mathrm{~V}$ & 68.54 & V & 71.25 & $\mathrm{~V}$ & $2.09^{*}$ \\
\hline 6. & High cost of DTH service. & 67.92 & V & 72.5 & IV & 69.17 & IV & 66.67 & VI & 68.55 & IV & 69.59 & VI & $2.69^{*}$ \\
\hline 7. & High cost of HYV seeds & 63.33 & VII & 66.25 & VII & 58.33 & VIII & 59.17 & VII & 60.83 & VII & 62.71 & VII & 1.51 \\
\hline 8. & High cost of equipments (sprays and dusters) & 55.83 & VIII & 61.67 & VIII & 61.67 & VII & 56.67 & VIII & 58.75 & VIII & 59.17 & VIII & $2.65^{*}$ \\
\hline
\end{tabular}

* = significant at 5 per cent level of significance

\section{CONCLUSIONS}

- Among all the categories of constraints the technical constraints were perceived as the most severe constraints by all the aonla growing farmers and farm women.

- Technical constraints the "Lack of farm magazines / newspapers" was perceived as the most severe technical constraints by aonla growing farmers and farm women.

- Operational constraints it was found that the aonla growing farmers and farm women "Less uses of local language in TV/Radio/Newspaper" was perceived as the most severe operational constraints.

- Infra-structural constraints it was found that the aonla growing farmers and farm women "Lack of Email/internet facilities" (MPS 84.29 and 84.42 respectively) as perceived as the most severeinfra-structural constraints.

- Educational constraints the aonla growing farmers "Lack of time for accessing the information" whereas, the farm women "Poor education/literacy of respondents" were perceived as the most severe educational constraints.

- Economic constraints the aonla growing farmers and farm women "High charge of traveling ticket" was perceived as the most severe economic constraints. There was a significant correlation between the aonla growing farmers and farm women with respect to their perception of the constraints in agriculture information management.

\section{RECOMMENDATIONS}

- It was also noted that extension contact between aonla growers and extension workers (other than agriculture supervisor) was not much satisfactory. So, necessary actions should be taken to increase the frequency of farm visits of the extension workers which will enable to identify the local problems, needs and indigenous technologies of the aonla growers.

- It is suggested to increase the space in newspapers to cover more agricultural information. The language of 
agricultural information in the newspapers is simple because majority of rural information seekers are less educated. So more illustrated technical knowledge should be given to them.

\section{REFERENCES}

1. Dhayal, B. L. (2006). “Communication behaviour of ber growers in Chomu Tehsil of Jaipur District of Rajasthan”. M.Sc. Thesis RAU, Bikaner, Campus-Jobner.

2. Dhayal, B. L., Khan,I.M. and Jangid, M. K. (2012)."Information seeking information of ber growers in Jaipur District of Rajasthan.” Rajasthan Journal of Extension Education, vol. 20 ,pp. 57-60

3. Narinder Paul, Panjab, N.K. And Shoshi Paul (2001). "Social-economic constraints in development of mushroom enterprises". Indian Journal of Extension Education..37:(1\&2), pp. 63-68.

4. Ravishankar, R.L. And Katteppa, Y. (1998). “Constraints analysis of potato growers.Indian Journal of Extension Education”.9 (4), pp. 2201-2204.

5. Resmy, C., Shivamurthy, M. and Varshatapre (2001). "Constraints in adoption of suitable practices in coconut and banana". Indian Journal of Extension Education, 37(1\&2), pp. 99-101

6. Yadav, B.S. (2009). “Information Seeking Behaviour of Fenugreek Growers in Jaipur Region of Rajasthan.” Ph.D. Thesis, RAU, Bikaner, Campus-Jobner 